\title{
Metamorphic evolution and U-Pb zircon SHRIMP geochronology of the Belizário ultramafic amphibolite, Encantadas Complex, southernmost Brazil
}

\author{
LÉO A. HARTMANN ${ }^{1}$, JOÃo O.S. SANTOS ${ }^{2}$, JAYME A.D. LEITE $^{3}$, \\ CARLA C. PORCHER ${ }^{1}$ and NEAL J. McNAUGHTON ${ }^{4}$ \\ ${ }^{1}$ Instituto de Geociências, Universidade Federal do Rio Grande do Sul, 91500-000 Porto Alegre, RS, Brasil \\ ${ }^{2}$ Brazilian Geological Survey - CPRM, 90840-030 Porto Alegre, RS, Brasil \\ ${ }^{3}$ Departamento de Recursos Minerais - ICET, Universidade Federal do Mato Grosso, 78060-900 Cuiabá, MT, Brasil \\ ${ }^{4}$ Centre for Global Metallogeny, University of Western Australia, Nedlands 6907, WA
}

Manuscript received on June 20, 2002; accepted for publication on May 7, 2003;

contributed by LÉO A. HARTMANN*

\begin{abstract}
The integrated investigation of metamorphism and zircon U-Pb SHRIMP geochronology of the Belizário ultramafic amphibolite from southernmost Brazil leads to a better understanding of the processes involved in the generation of the Encantadas Complex. Magmatic evidence of the magnesian basalt or pyroxenite protolith is only preserved in cores of zircon crystals, which are dated at $2257 \pm 12 \mathrm{Ma}$. Amphibolite facies metamorphism $\mathrm{M}_{1}$ formed voluminous hornblende in the investigated rock possibly at $1989 \pm 21 \mathrm{Ma}$. This ultramafic rock was re-metamorphosed at $702 \pm 21$ Ma during a greenschist facies event $\mathrm{M}_{2}$; the assemblage actinolite + oligoclase + microcline + epidote + titanite + monazite formed by alteration of hornblende. The metamorphic events are probably related to the Encantadas Orogeny (2257 $\pm 12 \mathrm{Ma}$ ) and Camboriú Orogeny ( 1989 Ma) of the Trans-Amazonian Cycle, followed by an orogenic event (702 $\pm 21 \mathrm{Ma})$ of the Brasiliano Cycle. The intervening cratonic period (2000-700 Ma) corresponds to the existence of the Supercontinent Atlantica, known regionally as the Rio de la Plata Craton.
\end{abstract}

Key words: ultramafic amphibolite, zircon geochronology, Encantadas Complex, Trans-Amazonian Cycle, metamorphism.

\section{INTRODUCTION}

A large advance in the understanding of metamorphic rocks is the identification of reactions responsible for the formation of mineral assemblages integrated with the dating of the recrystallization events. The mineral assemblages are commonly identified under the petrographic microscope, but more advanced investigations are required for the characterization of the reactions occurring in the rock. Chem-

* Member of Academia Brasileira de Ciências

Correspondence to: Léo A. Hartmann

E-mail: leo.hartmann@ufrgs.br ical analyses of minerals with the electron microprobe are necessary for the correct characterization of the processes involved.

In metamorphosed ultramafic rocks, the dating of the magmatic and metamorphic processes is hindered by the very low content in accessory minerals zuch as zircon (e.g., Heaman and Parrish 1991). The search for the adequate accessory minerals may be a rewarding task, because the age obtained will establish tight constraints on the evolution of the investigated region. 
Metamorphosed ultramafic rocks occur in southern Brazil, such as in the Encantadas Complex in the core of the Porongos Belt (Hartmann et al. 1999, 2000b). The complex is dominantly a tonalite-trondhjemite-granodiorite association, but it also contains marbles and calc-silicate rocks (e.g. Porcher and Fernandes 1990, Fernandes et al. 1992). Several hundred meter-long enclaves of ultramafic amphibolite occur (Figs. 1 and 2) near the Belizário Creek in the Santana da Boa Vista region, state of Rio Grande do Sul, southernmost Brazil, but their stratigraphic position remains undetermined, because they may be either part of the Encantadas Complex or intrusive into the complex (Remus et al. 1990, Philipp and Viero 1995). The ages of the Encantadas Complex tonalites and the regionally related Porongos supracrustal rocks were recently determined as Paleoproterozoic (Hartmann et al. 2000a), making more significant the determination of the age of the ultramafic rocks.

One rock sample from the Belizário ultramafic amphibolite body was investigated for the characterization of its metamorphic and geochronologic evolution, using an electron microprobe and a sensitive high resolution ion microprobe (SHRIMP II) - 32 electron microprobe chemical analyses and 8 spot isotopic analyses in 8 grains. The metamorphic and temporal evolution of this metamorphosed ultramafic amphibolite is the scope of this investigation.

\section{GEOLOGICAL RELATIONSHIPS}

The ultramafic rocks of southern Brazil are contained in a variety of rock associations ranging from Archean granite-greenstone and granulite terrains to Neoproterozoic granitic rocks and ophiolites (Hartmann 1998, Hartmann et al. 1999, 2000a, Leite et al. 1998, 2000, Hartmann and Remus 2000). This implies that the ultramafic rocks occur in a great variety of geological environments, including a deep crustal granulite facies domain, middle crustal ophiolites and shallow level supracrustal associations, in addition to small peridotite bodies in basic stratiform complexes.
The Porongos Belt is made up mostly of terrigenous sedimentary rocks and acid volcanic rocks, but includes marbles and calc-silicate rocks. It also includes ophiolitic ultramafic rocks in the northern portion (Marques 1996). Septa of the Encantadas Complex cover a large area in the core of the Porongos Belt in the Santana da Boa Vista region (Fig. 2). The complex contains tonalites, trondhjemites, granodiorites and monzogranites, intensely deformed in amphibolite facies conditions. Mafic and ultramafic amphibolites form 100-500 m large bodies (Remus et al. 1990). One of these ultramafic bodies was sampled for this investigation.

\section{MATERIALS AND METHODS}

Field mapping was followed by sample collection and preparation for electron microprobe and SHRIMP analyses. Polished thin sections were investigated with a CAMECA SX-50 electron microprobe at "Centro de Estudos em Petrologia e Geoquímica, Instituto de Geociências, Universidade Federal do Rio Grande do Sul', Porto Alegre, Brazil, for the chemical composition of minerals and the micro-structural relationships were observed in backscattered electron images. MinPet software was used for calculation and plotting of mineral compositions.

Preparation for isotopic studies involved zircon separation by crushing and sieving, and then heavy liquid and magnetic separation. After hand picking, the zircon crystals were mounted on an epoxy disc, polished to half their thickness and carbon coated for backscattered electron (BSE) imaging. The coating was later removed for gold coating before SHRIMP II U-Pb isotopic determinations on the zircon crystals in Perth, Western Australia. SHRIMP II analyses followed the procedures of Compston et al. (1992) and Smith et al. (1998).

\section{SAMPLE DESCRIPTION}

The ultramafic amphibolite sample was collected on the top of a hill in a small outcrop, because the soil cover is thick and rock exposures are small. The sample is massive, unfoliated, dark green, com- 


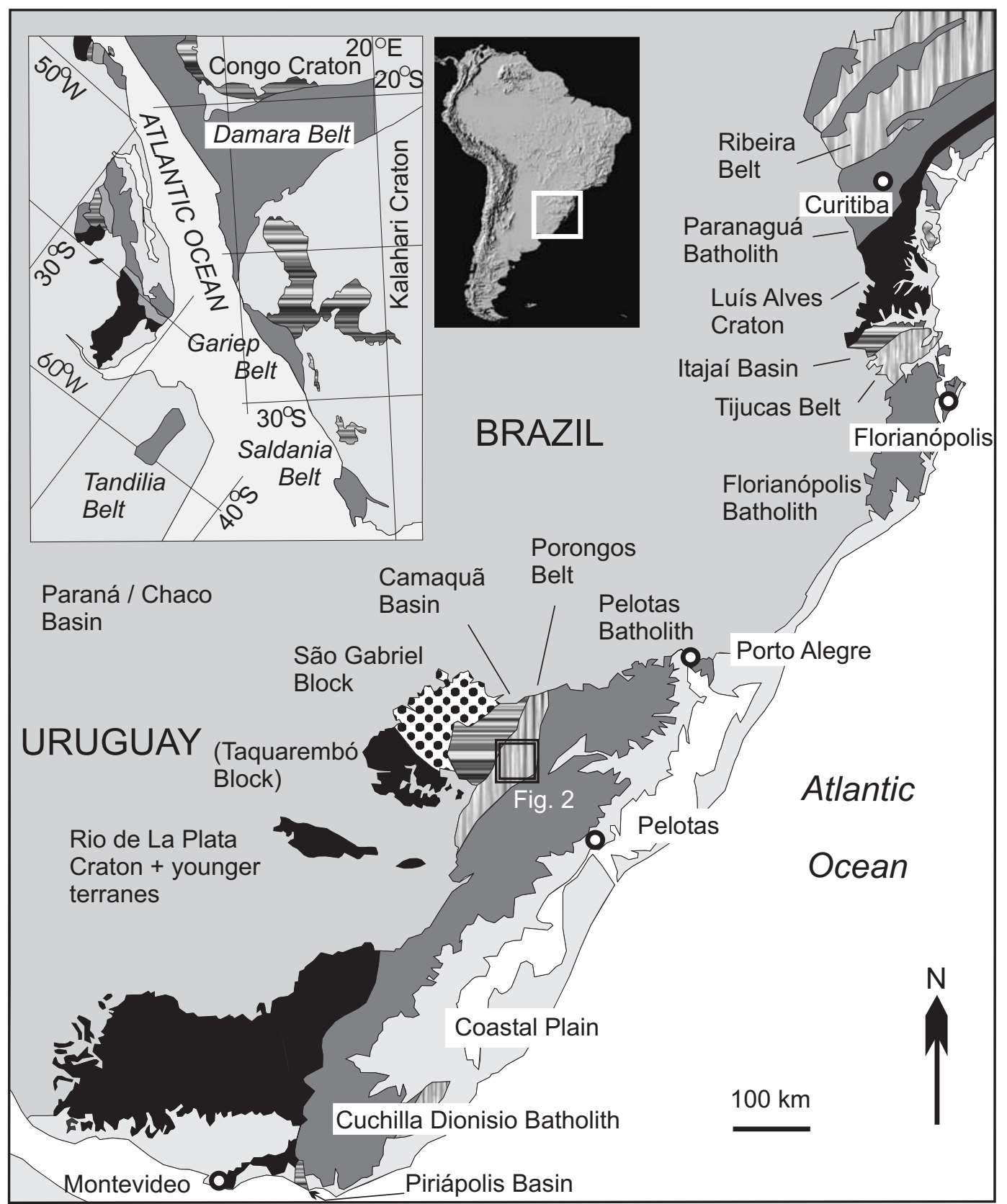

Fig. 1 - Geological map of southern Brazil, showing location in South America and correlation with southern Africa. Location of Figure 2 indicated.

posed mostly by amphiboles and containing light grey patches and veins of plagioclase (Fig. 3). Grain size of amphibole crystals is bimodal about $0.5-1.0$ and $0.1 \mathrm{~cm}$.

The amphiboles are of two types (Table I,
Fig. 4) and each makes up nearly half the volume of the rock. One amphibole type comprises large metamorphic $\mathrm{M}_{1}$ crystals of green hornblende, $\mathrm{n}_{\mathrm{g}}$ $=$ bluish green, $\mathrm{n}_{\mathrm{m}}=$ medium green, $\mathrm{n}_{\mathrm{p}}=$ colorless, $n_{g}>n_{m}>n_{p}$. The other type corresponds to the 


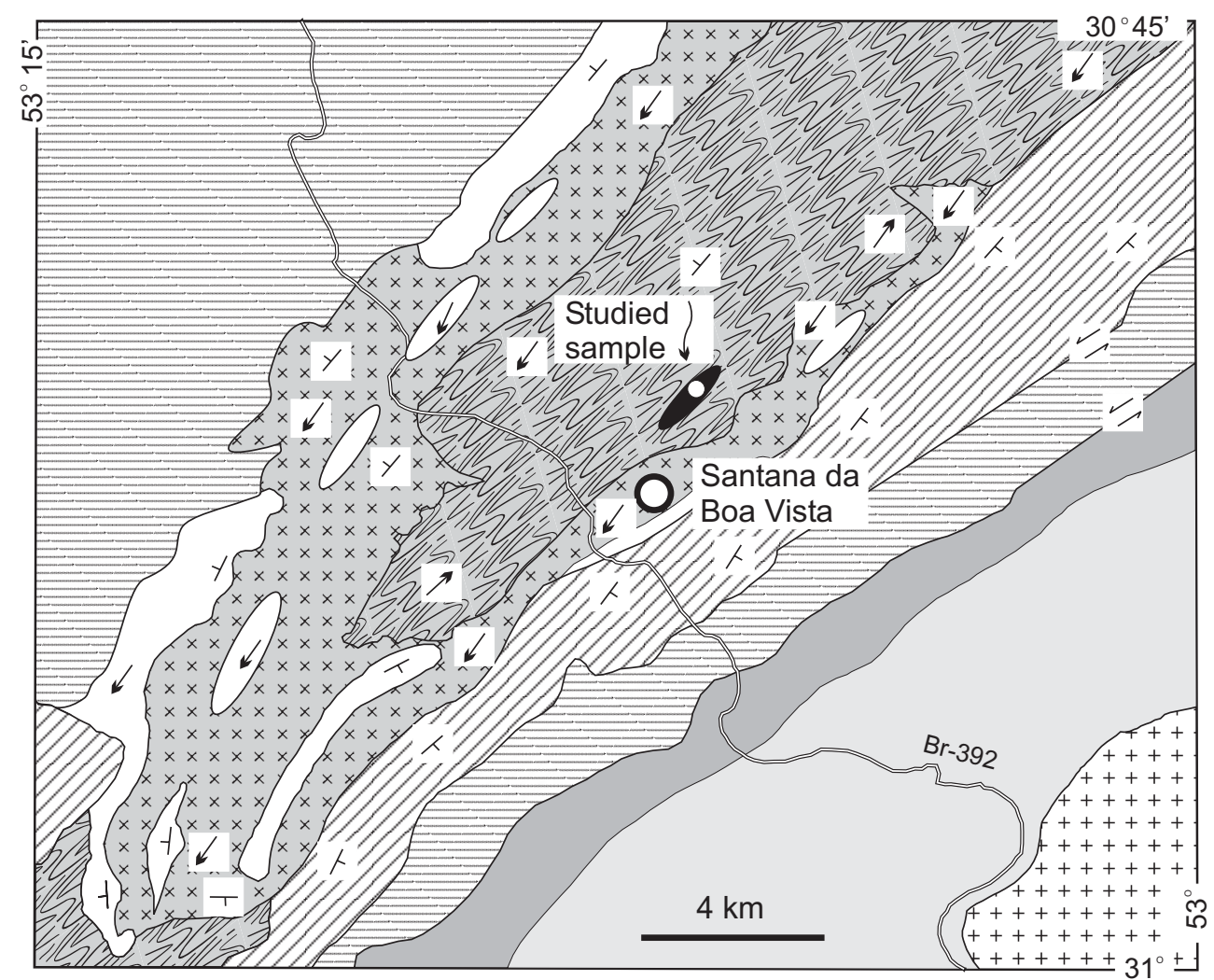

$\downarrow \quad$ Stretching lineation

\section{CONVENTIONS}

^ Gneissic foliation

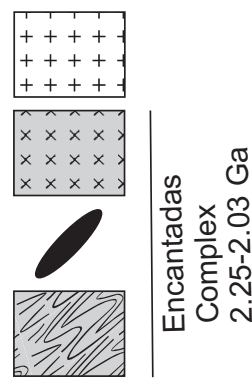

Dom Feliciano Belt, granitic rocks, 650-590 Ma

Mylonitic monzogranite, syenogranite

Belizário ultramafic amphibolite

Gneissic-migmatitic tonalite, trondhjemite

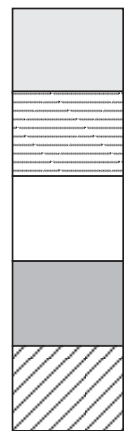

Paraná Basin sedimentary rocks, 350-0 Ma

Camaquã Basin, clastic sediments, $590 \mathrm{Ma}$

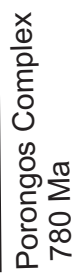

\section{Quartzite}

Mafic metavolcanic rocks, age unknown

Pelitic schist

Fig. 2 - Geological map of the Santana da Boa Vista region (from Hartmann et al. 2000b). Location of studied ultramafic amphibolite sample indicated.

metamorphic $\mathrm{M}_{2}$ rims on the green hornblendes and to abundant small granoblastic crystals, very light bluish/green to colorless actinolites. Oligoclase $\left(\mathrm{n}=5 ; \mathrm{An}_{25} \mathrm{Ab}_{74.2} \mathrm{Or}_{0.8}\right)$ is interstitial and occurs also in fractures; some ragged aggregates of plagioclase crystals are included in hornblende. Microcline $\left(\mathrm{n}=1 ; \mathrm{Or}_{96.6} \mathrm{Ab}_{3.1} \mathrm{An}_{0.3}\right)$ occurs in small amounts.
Three geological events occurred, but the original magmatic features of the first event were erased by the two metamorphic recrystallization events. $\mathbf{M}_{1}$ amphibolite facies metamorphism recrystallized the probable pyroxenitic protolith into a nearly monomineralic hornblende rock. $\mathrm{M}_{2}$ followed in the greenschist facies. These two meta- 
morphic episodes were accompanied by low intensity deformation, because no major foliation or lineation are observed. A complex chemical reaction altered the metamorphic hornblende into a set of lower grade minerals, as described below.

\section{THE METAMORPHIC REACTION $\mathrm{M}_{1} \rightarrow \mathrm{M}_{2}$}

The $\mathrm{M}_{1}$ amphibole (Fig. 4) is a low aluminum about 9 wt. $\% \mathrm{Al}_{2} \mathrm{O}_{3}$, magnesia-hornblende also low in titanium - about $0.5 \mathrm{wt} . \% \mathrm{TiO}_{2}$. The hornblende has significant contents (Table I) of sodium - about 0.7 wt. $\% \mathrm{Na}_{2} \mathrm{O}$ and potassium - about 0.4 wt. $\%$ $\mathrm{K}_{2} \mathrm{O}$. The hornblende has $\mathrm{Cr}_{2} \mathrm{O}_{3}$ contents about 0.1 wt.\% in four analyzed crystals, which indicates a magmatic protolith for the amphibolite. The $\mathrm{M}_{2}$ amphibole is an actinolite (Fig. 4) because $\mathrm{Al}_{2} \mathrm{O}_{3}$ is low - 1-2 wt. $\% \mathrm{Al}_{2} \mathrm{O}_{3}$. These amphiboles are typical of amphibolite $\left(\mathrm{M}_{1}\right)$ and greenschist $\left(\mathrm{M}_{2}\right)$ facies conditions.

The careful investigation of the microstructure and mineralogy by energy dispersive system (EDS) and wavelength dispersive system (WDS), associated with backscattered electron (BSE) images led to the identification of the reaction that transformed the ultramafic amphibolite partly into an ultramafic greenschist. The following reaction:

hornblende $=$ actinolite + oligoclase + microcline + epidote + titanite + monazite

explains the $\mathrm{M}_{1}$ and $\mathrm{M}_{2}$ assemblages and microstructures observed. The equation cannot be balanced, because the reaction occurred in open-system conditions: the $\mathrm{M}_{2}$ minerals are present in the crosscutting fractures, which indicates that part of the chemical components may have migrated to higher crustal levels during $\mathrm{M}_{2}$. The monazite formed along with the $\mathrm{M}_{2}$ mineral assemblage, therefore in the greenschist facies.

The cations present in hornblende were redistributed in the new mineral assemblage. Calcium is now mostly in actinolite, because actinolite is the most voluminous $\mathrm{M}_{2}$ phase, but some calcium is in oligoclase, epidote and titanite. All these $\mathrm{M}_{2}$ minerals are absent from the $\mathrm{M}_{1}$ assemblage. Titanium is concentrated in titanite in the new assemblage, but aluminum is concentrated in oligoclase and some in epidote. Actinolite is more siliceous than hornblende, which led to the availability of $\mathrm{SiO}_{2}$ for the crystallization of other silicates. Higher rare earth element (REE) contents are present in hornblende crystals as is indicated by their higher $\mathrm{TiO}_{2}$ contents when compared with actinolite. Higher rare earth element (REE) contents are present in hornblende crystals as is indicated by their higher $\mathrm{TiO}_{2}$ contents when compared with actinolite. The REE concentrated during $\mathrm{M}_{2}$ in titanite and the light REE in monazite. The hornblende crystals have much higher $\mathrm{Na}_{2} \mathrm{O}$ and $\mathrm{K}_{2} \mathrm{O}$ than the actinolite, which led to the formation of oligoclase and microcline. $\mathrm{Cr}_{2} \mathrm{O}_{3}$ was liberated from the amphibole during the reaction hornblende to actinolite, and is probably concentrated in the other $\mathrm{M}_{2}$ mafic minerals, because it is not present in the same amount in the actinolite. The iron content of actinolite is lower than in hornblende, which led to the formation of epidote, probably associated with higher partial pressure of oxygen to form some $\mathrm{Fe}^{+3}$. Actinolite is more magnesian than hornblende; this is the reason for the absence of other magnesian minerals in the $\mathrm{M}_{2}$ assemblage. The phosphorous necessary for the formation of $\mathrm{M}_{2}$ monazite probably originated in some unobserved $\mathrm{M}_{1}$ apatite.

The formation of monazite during $\mathrm{M}_{2}$ from the breakdown of $\mathrm{M}_{1}$ hornblende can be used as a chronometer for the timing of the greenschist facies metamorphic event. This will be attempted in future investigations.

\section{SHRIMP GEOCHRONOLOGY}

The observation of twelve BSE images of zircon crystals shows that few euhedral forms are preserved (Fig. 5); most crystals are rounded or have irregular shapes. The crystals have some mineral inclusions and some are very porous. An outstanding feature is the presence of dark grey, homogeneous cores rimmed by light grey portions. The cores are interpreted as remnant magmatic portions and the rims as parts of the crystals which were metamorphosed. On 


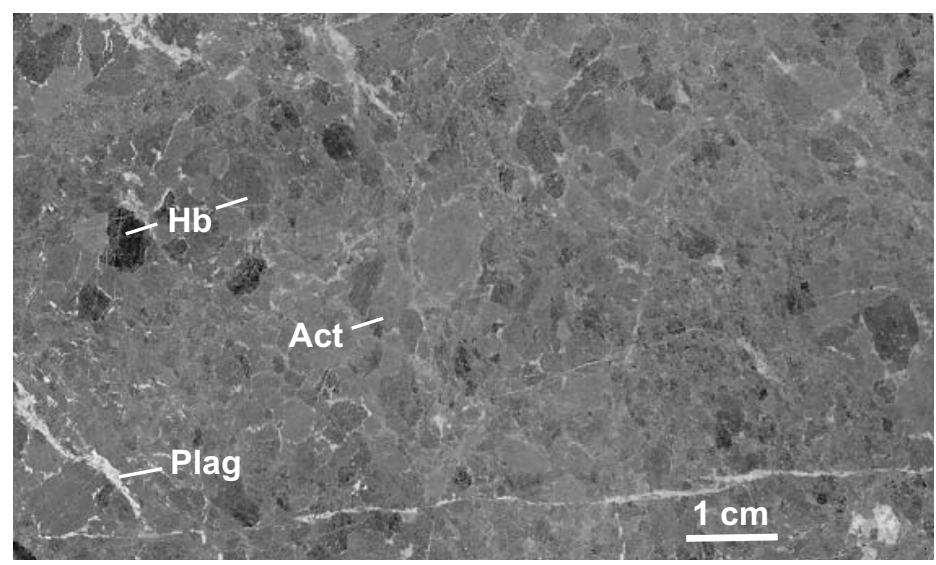

Fig. 3 - Scanned hand sample of Belizário ultramafic amphibolite shows darker hornblende and lighter actinolite crystals in equivalent contents; plagioclase is present in matrix and in many large and small veins.

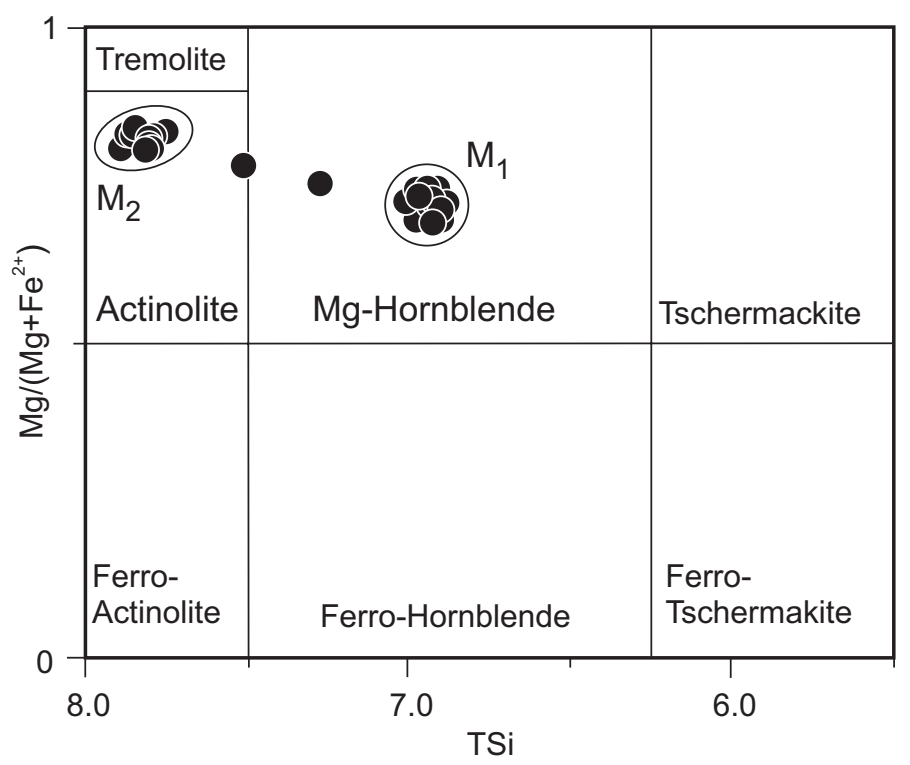

Fig. $4-\mathrm{M}_{1}$ hornblende and $\mathrm{M}_{2}$ actinolite compositions from the investigated sample. Two analyses are intermediate between the two extreme compositions because of partial resetting during greenschist facies metamorphic event.

the other hand, the distribution of the two textures, respectively dark and light grey in BSE images, is irregular and gradational. This texture made it nearly impossible to select homogeneous portions of the crystals for spot SHRIMP dating; the results may correspond to mixed isotopic compositions. The mixing of the magmatic and metamorphic isotopic compositions can lead to discordant results.

Eight U-Pb isotopic analyses of six zircon crystals (Table II) from the ultramafic amphibolite yield an array of discordant spots and one nearly concordant spot (Fig. 6). The seven discordant analyses are 
TABLE I

Selected electron microprobe chemical analyses of amphiboles from the dated ultramafic amphibolite sample. Total number of analyses $=26 ; 0.00=$ below detection limit.

\begin{tabular}{l|c|c|c|c|c|c}
\hline Analysis & 1 & 2 & 3 & 4 & 5 & 6 \\
\hline $\mathrm{SiO}_{2}$ & 56.05 & 48.24 & 55.87 & 47.95 & 56.58 & 47.59 \\
$\mathrm{TiO}_{2}$ & 0.02 & 0.66 & 0.00 & 0.55 & 0.02 & 0.56 \\
$\mathrm{Al}_{2} \mathrm{O}_{3}$ & 1.51 & 8.71 & 1.80 & 8.73 & 1.40 & 8.91 \\
$\mathrm{FeO}$ & 7.92 & 11.47 & 7.64 & 11.96 & 7.71 & 12.21 \\
$\mathrm{Cr}_{2} \mathrm{O}_{3}$ & 0.03 & 0.16 & 0.00 & 0.11 & 0.00 & 0.10 \\
$\mathrm{MnO}$ & 0.16 & 0.18 & 0.26 & 0.23 & 0.16 & 0.16 \\
$\mathrm{MgO}$ & 19.17 & 14.52 & 19.04 & 14.56 & 19.38 & 14.15 \\
$\mathrm{CaO}$ & 12.55 & 11.91 & 12.92 & 12.06 & 12.99 & 12.37 \\
$\mathrm{Na}_{2} \mathrm{O}$ & 0.18 & 0.87 & 0.11 & 0.90 & 0.10 & 0.81 \\
$\mathrm{~K}_{2} \mathrm{O}$ & 0.05 & 0.57 & 0.04 & 0.58 & 0.04 & 0.61 \\
$\mathrm{~F}$ & 0.10 & 0.56 & 0.31 & 0.45 & 0.78 & 0.00 \\
$\mathrm{Total}$ & 97.74 & 97.85 & 97.99 & 98.08 & 99.16 & 97.47 \\
$\mathrm{H}_{2} \mathrm{O}$ & 2.08 & 1.78 & 1.98 & 1.83 & 1.77 & 2.06 \\
Event & $\mathrm{M} 2$ & $\mathrm{M} 1$ & $\mathrm{M} 2$ & $\mathrm{M} 1$ & $\mathrm{M} 2$ & $\mathrm{M} 1$ \\
\hline
\end{tabular}

aligned between an upper intercept of $2257 \pm 12 \mathrm{Ma}$ and a lower intercept of $702 \pm 21 \mathrm{Ma}$. One spot is nearly concordant at $1989 \pm 21 \mathrm{Ma}$.

The age of $2257 \pm 12 \mathrm{Ma}$ is interpreted as the magmatic age of the protolith, probably a pyroxenite or a magnesian basalt. This age is in close agreement with the magmatic age of a tonalite from the Encantadas Complex dated with zircon U-Pb SHRIMP by Hartmann et al. (2000a) at $2256 \pm 8 \mathrm{Ma}$. The tonalite also yielded a metamorphic age of $2052 \pm 5 \mathrm{Ma}$ (Hartmann et al. 2000a), and the age (one spot) of about $1899 \mathrm{Ma}$ in the ultramafic amphibolite was probably caused by the same metamorphic $\mathrm{M}_{1}$ event that affected the tonalite or by partial lead loss during the Neoproterozoic event. Additional investigations are required to identify the geological process that originated the isotopic compositions related to the 1899 Ma age.

The age of $702 \pm 21 \mathrm{Ma}$ is interpreted as the consequence of the Neoproterozoic metamorphism $\mathrm{M}_{2}$ that affected the ultramafic amphibolite during the Brasiliano Cycle. This may be therefore the time when the reaction of an amphibolite fa- cies assemblage to a greenschist facies assemblage described above occurred. Because a long extrapolation is required, this age is only an approximation, although ages of tectonic events near 750-700 Ma are known in the southern Brazilian Shield as an important event of the Brasiliano Cycle (Hartmann et al. 2000a).

\section{DISCUSSION AND CONCLUSIONS}

The reaction hornblende $=$ actinolite + oligoclase + microcline + epidote + titanite + monazite is identified in the Belizário ultramafic amphibolite, Encantadas Complex. This indicates changing conditions from severe $M_{1}$ amphibolite facies conditions to less intense $\mathrm{M}_{2}$ greenschist facies metamorphism. The redistribution of cations after part of the hornblende crystals became unstable to form actinolite and the other minor minerals is explained by careful observation of images integrated with qualitative and quantitative chemical analyses.

The older ages identified in the sample correspond to the Trans-Amazonian Cycle (see Almeida et al. 2000) of orogenies, known to range from 2.26 

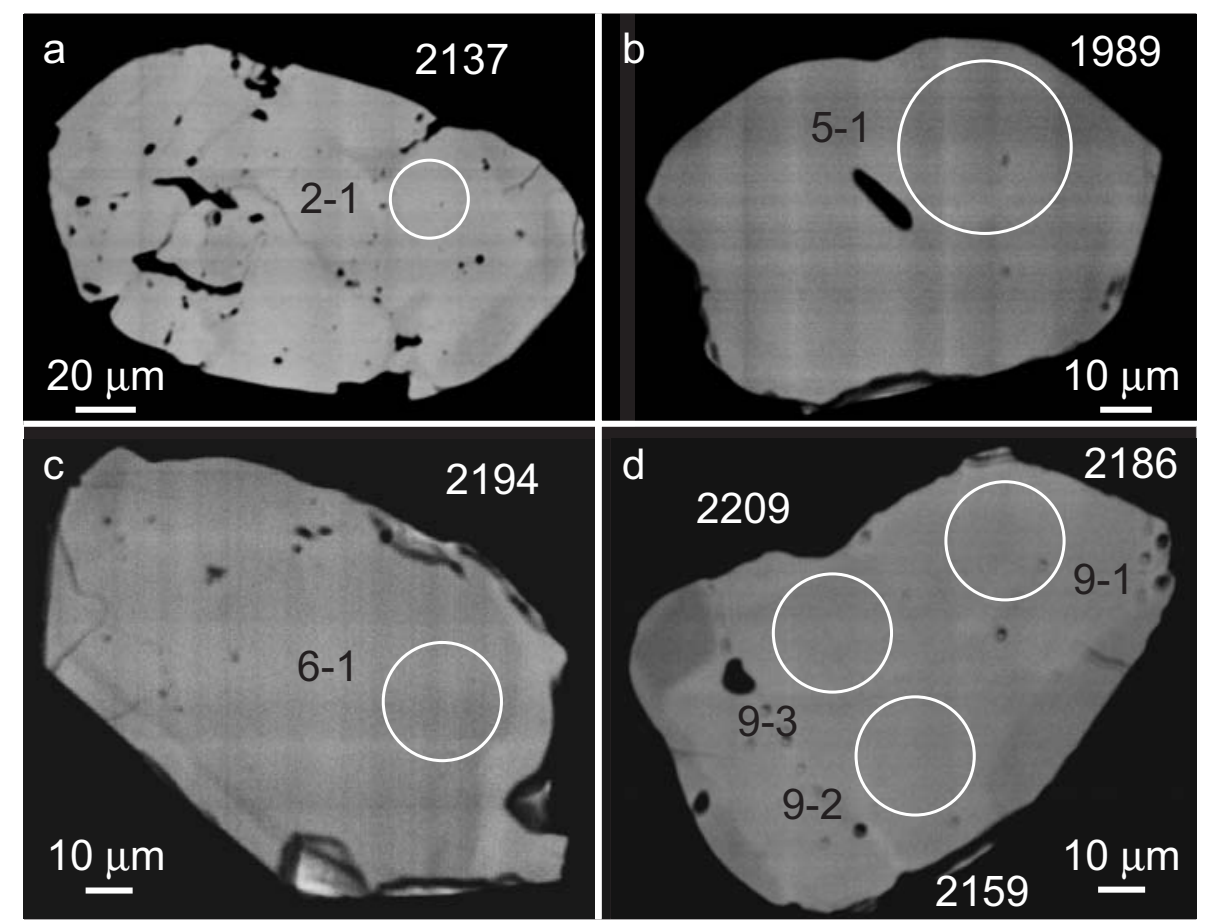

Fig. 5 - Backscattered electron images of zircon crystals from the studied sample. White circles indicate position of SHRIMP isotopic analyses; spots number and ages (Ma) indicated.

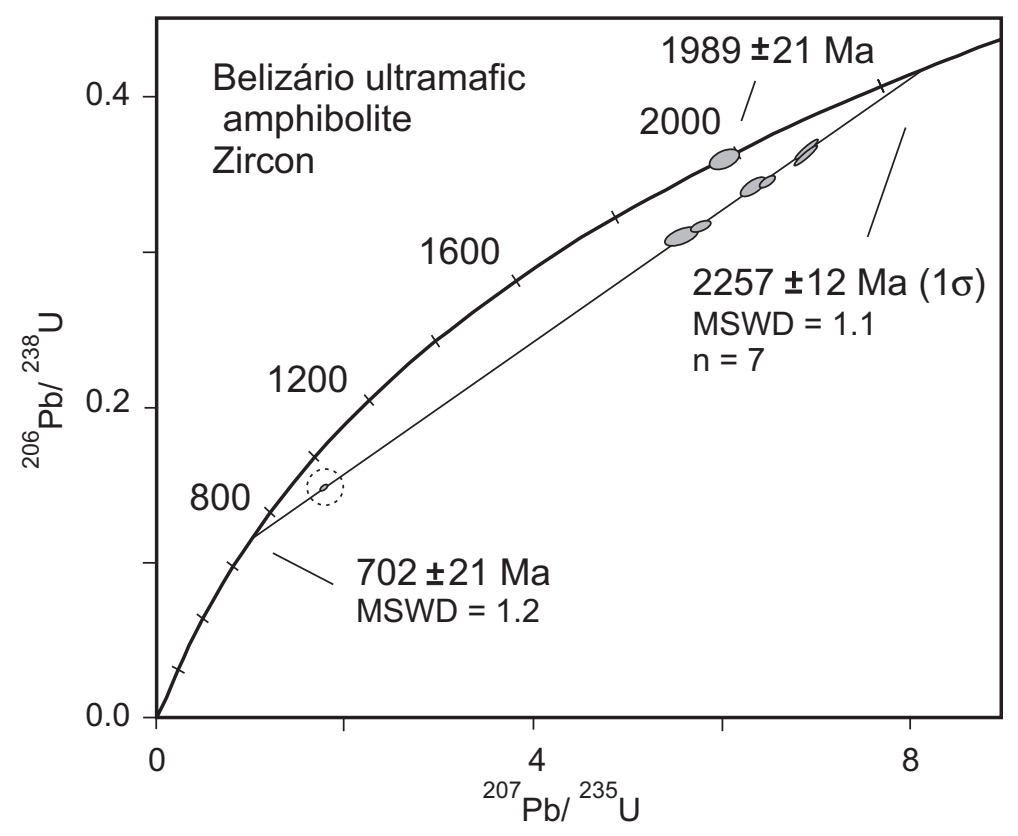

Fig. 6-Concordia diagram of SHRIMP analyses of zircon crystals from studied rock. One analysis enhanced with a discontinuous circle. 
TABLE II

Zircon U-Pb SHRIMP isotopic data for the ultramafic amphibolite.

\begin{tabular}{l|c|c|c|c|c|c|c}
\hline $\begin{array}{l}\text { Spot } \\
\text { no. }\end{array}$ & $\begin{array}{c}\mathrm{U} \\
\mathrm{ppm}\end{array}$ & $\mathrm{Th} / \mathrm{U}$ & $\begin{array}{c}f 206 \\
\%\end{array}$ & $\begin{array}{c}{ }^{207} \mathrm{~Pb} / \\
{ }^{206} \mathrm{~Pb}\end{array}$ & \pm & $\begin{array}{c}{ }^{208} \mathrm{~Pb} / \\
206 \mathrm{~Pb}\end{array}$ & \pm \\
\hline $2-1$ & 358 & 0.14 & 0.001 & 0.1329 & 0.0007 & 0.0343 & 0.0010 \\
$3-1$ & 818 & 0.52 & 0.007 & 0.0873 & 0.0008 & 0.1473 & 0.0018 \\
$5-1$ & 111 & 0.32 & 0.004 & 0.1222 & 0.0014 & 0.0872 & 0.0027 \\
$6-1$ & 346 & 0.55 & 0.000 & 0.1373 & 0.0006 & 0.1570 & 0.0012 \\
$7-1$ & 148 & 0.14 & 0.018 & 0.1309 & 0.0022 & 0.0289 & 0.0040 \\
$9-1$ & 457 & 0.51 & 0.001 & 0.1367 & 0.0006 & 0.1405 & 0.0011 \\
$9-2$ & 215 & 1.74 & 0.001 & 0.1346 & 0.0009 & 0.4834 & 0.0028 \\
$9-3$ & 308 & 0.49 & 0.000 & 0.1385 & 0.0007 & 0.1426 & 0.0011 \\
\hline \hline & & & & & $\mathrm{Age}$ & & \\
$\mathrm{Spot}$ & $206 \mathrm{~Pb} /$ & \pm & $207 \mathrm{~Pb} /$ & \pm & $207 \mathrm{~Pb} /$ & \pm & $\mathrm{Conc}$. \\
no. & $238 \mathrm{~Pb}$ & & $235 \mathrm{~Pb}$ & & $206 \mathrm{~Pb}$ & & $\%$ \\
\hline $2-1$ & 0.316 & 0.003 & 5.79 & 0.07 & 2137 & 9 & 83 \\
$3-1$ & 0.148 & 0.001 & 1.78 & 0.02 & 1366 & 18 & 65 \\
$5-1$ & 0.359 & 0.004 & 6.05 & 0.11 & 1989 & 21 & 99 \\
$6-1$ & 0.366 & 0.004 & 6.92 & 0.08 & 2194 & 8 & 82 \\
$7-1$ & 0.310 & 0.004 & 5.59 & 0.12 & 2110 & 29 & 83 \\
$9-1$ & 0.344 & 0.003 & 6.48 & 0.07 & 2186 & 8 & 87 \\
$9-2$ & 0.342 & 0.004 & 6.34 & 0.09 & 2159 & 12 & 88 \\
$9-3$ & 0.362 & 0.004 & 6.91 & 0.08 & 2209 & 8 & 90 \\
\hline & & & & & & &
\end{tabular}

\# ratios corrected for common $\mathrm{Pb} ; f 206$ is the percentage of common $\mathrm{Pb}$ found in ${ }^{206} \mathrm{~Pb}$; Conc $=$ concordance $=100 \mathrm{t}\left({ }^{206} \mathrm{~Pb} /{ }^{238} \mathrm{U}\right) / \mathrm{t}\left({ }^{207} \mathrm{~Pb} /{ }^{206} \mathrm{~Pb}\right)$.

to 2.00 Ga in South America (Hartmann and Delgado 2001, Santos et al. 2003). The early Encantadas Orogeny - 2.26-2.10 Ga produced the magmatic tonalite-granodiorite association of the Encantadas Complex at $2257 \pm 12 \mathrm{Ma}$, including the pyroxenite or magnesian basalt protolith of the studied sample. This Encantadas Orogeny can be interpreted as an accretionary event of juvenile island arcs, because of the predominance of greenstone belts and TTG (tonalite-trondhjemite-granodiorite) rocks and isotopic geochemistry (Norcross et al. 2000, Hartmann et al. 2000a, Santos et al. 2000, 2003, Hartmann and Delgado 2001). The $\mathrm{M}_{1}$ metamorphic event of hornblende formation may have occurred at $1989 \pm 21 \mathrm{Ma}$ (one spot), because an age near 2000 Ma is recognized in the southern Brazilian Shield as the collisional Camboriú Orogeny (Hartmann et al. 2000a, Santos et al. 2003).

The southern Brazilian Shield was affected intensely by the Neoproterozoic Brasiliano Cycle of orogenies - 900-550 Ma, including a major event at about 750-700 Ma - the São Gabriel Orogeny (Hartmann et al. 2000a). Therefore, the age near $702 \pm 21$ Ma could be interpreted as due to the tectonic activity of the Brasiliano Cycle on the dated sample, although a long extrapolation is made in the discordia lower intercept.

A magnesian basalt (or pyroxenite) crystallized from magma at the beginning of the Paleoproterozoic Trans-Amazonian Cycle, later deformed in the amphibolite facies at the end of the same cycle and then deformed in the greenschist facies during the Neoproterozoic Brasiliano Cycle. The extended, intervening cratonic period (2000-700 Ma) 
corresponds to the existence of the Supercontinent Atlantica, known regionally as the Rio de la Plata Craton.

\section{ACKNOWLEDGMENTS}

The electron microprobe was acquired and installed at UFRGS with funds from PADCT-FINEP. The maintenance of the laboratory is presently financed by UFRGS and by the project of excellence in metallogeny and crustal evolution - PRONEX/ $\mathrm{CNPq} / \mathrm{UFRGS}$. Isotopic analyses were performed with the SHRIMP II in Perth, Western Australia, operated by a consortium between Curtin University of Technology, University of Western Australia and the Geological Survey of Western Australia, supported by the Australian Research Council. Access to the SHRIMP II was gained through collaboration with the Centre for Global Metallogeny, UWA. Two anonymous reviewers made some significant contributions to the manuscript.

\section{RESUMO}

O entendimento dos processos evolutivos do Complexo Encantadas no sul do Brasil foi aperfeiçoado através do estudo integrado do metamorfismo de um anfibolito ultramáfico e da geocronologia U-Pb SHRIMP de zircão. Os núcleos herdados de alguns cristais de zircão tem idades em torno de $2257 \pm 12$ Ma e constituem a única evidência preservada do protólito ígneo, que pode ter sido um basalto magnesiano ou um piroxenito. O metamorfismo $\mathrm{M}_{1}$ de fácies anfibolito formou abundante hornblenda na amostra investigada, possivelmente há 1989 21 Ma. Esta rocha ultramáfica foi re-metamorfizada talvez há cerca de $702 \pm 21$ Ma durante um evento $\mathrm{M}_{2}$ de fácies xistos verdes do metamorfismo regional. Durante o evento $\mathrm{M}_{2}$, a hornblenda foi recristalizada e formou a assembléia actinolita + oligoclásio + microclínio + epidoto + titanita + monazita. Estes eventos foram a manifestação da Orogênese Encantadas (2257 \pm 12 Ma) e da Orogênese Camboriú ( 1989 Ma) do Ciclo Transamazônico, seguidos por um evento orogênico (702 $\pm 21 \mathrm{Ma})$ do Ciclo Brasiliano. O período intra-cratônico entre 2000-900 Ma corresponde à estabilidade do Supercontinente Atlântica, cujos remanescentes são conhecidos como Cráton Rio de la Plata.
Palavras-chave: anfibolito ultramáfico, geochronologia de zircão, Complexo Encantadas, Ciclo Transamazônico, metamorfismo.

\section{REFERENCES}

Almeida FFM, Brito Neves BB and Carneiro CDR. 2000. The origin and evolution of the South American Platform. Earth Sci Rev 50: 77-111.

Compston W, Williams IS, Kirschvink JL, Zichao Z and Guogan M. 1992. Zircon U-Pb ages for the Early Cambrian time-scale. Jour Geol Soc London 149: 171-184.

Fernandes LAD, Tommasi A And Porcher CC. 1992. Deformation patterns in the southern Brazilian branch of the Pan-African Dom Feliciano Belt. Jour South Amer Earth Sci 5: 67-76.

Hartmann LA. 1998. Deepest exposed crust of Brazil - Geochemistry of Paleoproterozoic depleted Santa Maria Chico granulites. Gondwana Res 1: 331-334.

Hartmann LA and Delgado IM. 2001. Cratons and orogenic belts of the Brazilian Shield and their contained gold deposits. Min Dep 36: 207-217.

Hartmann LA and Remus MVD. 2000. Origem e evolução das rochas ultramáficas do Rio Grande do Sul desde o Arqueano até o Cambriano. In: Holz M And De Ros LF. Geologia do Rio Grande do Sul. Ed. CIGO/UFRGS, p. 53-78.

Hartmann LA, Nardi LVS, Formoso MLL, Remus MVD, Lima EF AND Mexias AS. 1999. Magmatism and metallogeny in the crustal evolution of Rio Grande do Sul shield, Brazil. Pesquisas (UFRGS/ Porto Alegre) 26: 45-63.

Hartmann LA, Leite JAD, Silva LC, Remus MVD, McNaughton NJ, Groves DI, Fletcher IR, Santos JOS AND VASCONCEllos MAZ. 2000a. Advances in SHRIMP geochronology and their impact on understanding the tectonic and metallogenic evolution of southern Brazil. Australian Jour Earth Sci 47: 829-844.

Hartmann LA, Porcher CC and Remus MVD. 2000 b. Evolução das rochas metamórficas do Rio Grande do Sul. In: Holz M And De Ros LF. (eds.) Geologia do Rio Grande do Sul. Ed. CIGO/UFRGS, p. 79-118.

Heaman L and Parrish R. 1991. U-Pb geochronology of accessory minerals. In: HEAMAN L AND LUDDEN JN (eds.) Applications of radiogenic isotope systems 
to problems in geology. Min Assoc Canada, Short Course Handbook 19: 59-102.

Leite JAD, Hartmann LA, McNaughton NJ AND Chemale F. 1998. SHRIMP U/Pb zircon geochronology of Neoproterozoic juvenile and crustalreworked terranes in southernmost Brazil. Int Geol Rev 40: 688-705.

Leite JAD, Hartmann LA, Fernandes LAD, McNaughton NJ, Soliani E, Koester E, Santos JOS AND VASCONCELlos MAZ. 2000. Zircon U-Pb SHRIMP dating of gneissic basement of the Dom Feliciano Belt, southernmost Brazil. Jour South Amer Earth Sci 13: 739-750.

Marques JC. 1996. Petrologia e metalogênese da Sequência metaultramáfica da Antiforme Capané, Suite Metamórfica Porongos, Cachoeira do Sul - RS. M.Sc. Dissertation, Universidade Federal do Rio Grande do Sul, 196 pp. (unpublished).

Norcross C, Davis DW, Spooner ETC and Rust A. 2000. U-Pb and $\mathrm{Pb}-\mathrm{Pb}$ age constraints on Paleoproterozoic magmatism, deformation and gold mineralization in the Omai area, Guyana Shield. Prec Res: 102: 69-86.

Philipp RP And Viero AP. 1995. Geologia dos anfibolitos associados ao Gnaisse Encantadas. In: 5 SIMP Nac Est Tect, Gramado, Abs, p. 67-68.

Porcher CC AND Fernandes LAD. 1990. Relações embasamento-cobertura na porção ocidental do Cinturão Dom Feliciano: um esboço estrutural. Pesquisas (Porto Alegre) 17: 72-84.
Remus MVD, Philipp RP, FACCINI UF AND Junges SL. 1990. Contribuição ao estudo geológico-estrutural dos Gnaisses Encantadas e das relações com as supracrustais Porongos na região de Santana da Boa Vista, RS. $36^{\circ}$ Congr Bras Geol, Natal. Soc Bras Geol, Anais 5: 2358-2370.

Santos JOS, Hartmann LA, Gaudette HE, Groves DI, McNaughton NJ and Fletcher IR. 2000. A new understanding of the provinces of the Amazon Craton based on integration of field mapping and $\mathrm{U}$ $\mathrm{Pb}$ and Sm-Nd geochronology. Gondwana Res 3: 453-488.

Santos JOS, Hartmann LA, Bossi J, Campal N, Schipilov A, Piñeyro D and McNaughton NJ. 2003. Duration of the Trans-Amazonian Cycle and its correlation within South America based on U$\mathrm{Pb}$ SHRIMP geochronology of the La Plata Craton, Uruguay. Int Geol Rev 45: 27-48.

Smith JB, Barley ME, Groves Di, Krapez B, McNaughton NJ, Bickle J and Chapman HJ. 1998. The Scholl Shear Zone, West Pilbara: evidence for a domain boundary structure from integrated tectonostratigraphic analyses, SHRIMP U/Pb dating and isotopic and geochemical data of granitoids. Prec Res 88: 143-171. 